\title{
Hypoglycemic and Hypolipidemic Activities of Ethanolic Extract from Mimosa pudica L. in Normal and Streptozotocin-Induced Diabetic Rats
}

\author{
Piyapong Yupparach, Ampa Konsue*
}

\section{Piyapong Yupparach,} Ampa Konsue* Faculty of Medicine, Mahasarakham University, Maha Sarakham, 44000, THAILAND.

\section{Correspondence}

Ampa Konsue

Faculty of Medicine, Mahasarakham University, Maha sarakham, 44000, THAILAND.

Phone no: +66-4371-2992

E-mail: ampa_ice@hotmail.com

History

- Submission Date: 03-06-2017:

- Review completed: 17-07-2017;

- Accepted Date: 27-08-2017

DOI : 10.5530/pj.2017.6.130

Article Available online

http://www.phcogj.com/v9/i6

\section{Copyright}

(C) 2017 Phcog.Net. This is an openaccess article distributed under the terms of the Creative Commons Attribution 4.0 International license.

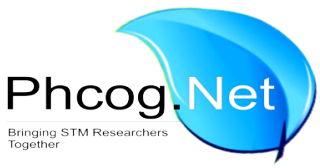

\begin{abstract}
Context: Mimosa pudica L. its unique property to collapse when touched and opens up. Aims: To evaluate hypoglycemic and hypolipidemic activities of $80 \%$ ethanolic extract from whole plant of Mimosa pudica L. (MPE) by measuring fasting blood glucose in normal and streptozotocin (STZ)-induced diabetic rats treated with MPE. Materials and Methods: An eight-week study using MPE was performed in normal and streptozotocin (STZ)-induced diabetic rats. Hypoglycemic activities in normal and STZ-induced diabetic rats and oral glucose tolerance test (OGTT) and biochemical data include total cholesterol (TC), triglycerides (TG), high-density lipoprotein (HDL) and low-density lipoprotein (LDL) of MPE were compared with glibenclamide, a standard anti-diabetic drug. Results: OGTT showed that MPE did not decrease blood glucose both in normal and STZ-induced diabetic rats comparable to controls and glibenclamide treated rats. Moreover, MPE did not affect FBG in the normal rats. However, it significantly $(p<0.05)$ decreased FBG in the diabetic rats while MPE increased HDL and decreased TC, TG and LDL in the diabetic rats. Conclusions: The results from this study confirmed the traditional use of Mimosa pudica $\mathrm{L}$. for the treatment of diabetes mellitus.

Key words: Mimosa pudica, Hypoglycemic, Hypolipidemic, Oral glucose tolerance test.
\end{abstract}

\section{INTRODUCTION}

Diabetes mellitus (DM) is a group of a metabolic disease of all age groups especially the middle age and aged people. Diabetes can cause serious complications that involve multiple organs and physiological functions. The chronic hyperglycemia of diabetes is associated with long-term damage, dysfunction and failure of various organs and systems. ${ }^{1} \mathrm{DM}$ is a chronic illness that requires continuous medical care and patient self-management education to prevent acute complications and to reduce the risk of long term complications. ${ }^{2}$ Type 2 diabetes, often associated with obesity, high blood glucose, blood lipid abnormalities, mainly increase levels of TC, TG, LDL-C, serum insulin and decrease levels of HDL-C, which lead to a series of complications. ${ }^{3}$ Many oral agents for the treatment of DM such as insulin, sulphonylureas, biguanides and thiazolidinediones are expensive and can cause adverse effects $^{4}$

Recently the traditional medicines from Thai medicinal plants including Mimosa pudica L. were used for the treatment of DM. ${ }^{5}$ Mimosa pudica L. is a medicinal plant belonging to family Fabaceae. It is particularities property to collapse when touched and opens up a few minutes later. Some pharmacological activities of this plant such as wound healing, ${ }^{6,7}$ analgesic, anti- inflammatory, ${ }^{8}$ anti-oxidant, ${ }^{9,10,11}$ hepatoprotective, ${ }^{11,12}$ hypolipidemic, ${ }^{13,14}$ anti-hyperglycemic, ${ }^{9,14,15,16}$ and hyperglycema. ${ }^{17}$ have been reported. Although this plant was widely used for treatment of diabetes, its hypoglycemic activity has not yet been reported. The present study was therefore, conducted to determine the hypoglycemic activity of $80 \%$ ethanolic extract from whole plant of Mimosa pudica L. in normal and STZ-induced diabetic rats.

\section{MATERIALS AND METHODS}

\section{Plant Materias/}

The fresh whole plants were collected from the moist waste ground along the road side in Kalasin Province, Northeastern Thailand. The specimen was identified by the Plant Varieties Protection Division, Department of Agriculture, Ministry of Agriculture and Cooperatives, Thailand. The voucher specimen is deposited at the Faculty of Medicine, Mahasarakham University, Thailand (code: MSU.Med-MP0001/ $\mathrm{AK})$. The plants were dried at $50^{\circ} \mathrm{C}$ for $48 \mathrm{~h}$ in a hot air oven and then powdered.

Cite this article: Yupparach P, Konsue A. Hypoglycemic and Hypolipidemic Activities of Ethanolic Extract from Mimosa pudica L. in Normal and Streptozotocin-Induced Diabetic Rats. Pharmacog J. 2017;9(6):834-7. 
Yupparach and Konsue: Hypoglycemic and Hypolipidemic Activities of Ethanolic Extract from Mimosa pudica L.

\section{Preparation of MPE}

MPE were prepared by macerating the plant powder in $80 \%$ ethanol for 7 days $(1: 5 \mathrm{w} / \mathrm{v})$. The residue powder was excluded by using the filter papers. The filtrate was evaporated using rotary evaporator (Heidolph Laborota 4000, Germany) and freeze-dried. The obtained dark brown extract with a percent yield of $5.74 \%$ dry powder was kept at $4^{\circ} \mathrm{C}$ until be used.

\section{Animals}

The using animals in this study were male albino Wistar rats weighing 150-200 g purchasing from the National Laboratory Animal Centre, Mahidol University, Thailand. They were acclimatized in an air-conditioned room at $25 \pm 2{ }^{\circ} \mathrm{C}, 12$-h light/12-h dark cycle with a relative humidity of $50-55 \%$. They were given with some standard chow and watered ad libitum for 7 days prior to the commencing experiment. The rats were maintained in accordance with the guidelines of the Committee Care and Use of Laboratory Animal Resource, National Research Council Thailand, and performed in accordance with the advice of the Institutional Animal Care and Use Committee, Mahasarakham University of Thailand (License, No. 0003/2017).

\section{Induction of diabetic rats}

The rats were injected intraperitoneally with a single dose of $65 \mathrm{mg} / \mathrm{kg}$ body weight (bw) streptozotocin (STZ, Sigma Chemicals, St. Louis, MO) dissolved freshly in cold $20 \mathrm{mM}$ citrate buffer $\mathrm{pH}$ 4.5. After injection, they were provided with $2 \%$ sucrose solution for $48 \mathrm{~h}$ to alleviate the discomfort after initiating the hypoglycemic phase. Three days after injection, the rats were examined for FBG to confirm their diabetic stage. The rats with FBG higher than $126 \mathrm{mg} / \mathrm{dL}$ were used in the experiments. ${ }^{18}$

\section{Oral glucose tolerance test (OGTT)}

The oral glucose tolerance test (OGTT) was performed on overnight fasting normal and STZ-induced diabetic rats. 0.5\% Tween 80, MPE ( $500 \mathrm{mg} / \mathrm{kg} \mathrm{bw})$ and glibenclamide $(0.5 \mathrm{mg} / \mathrm{kg} \mathrm{bw})$ were administered to six groups of the rats separately. Glucose $(1.25 \mathrm{~g} / \mathrm{kg} \mathrm{bw})$ was fed $30 \mathrm{~min}$ after a pretreatment with $0.5 \%$ Tween $80, \mathrm{MPE}$ and glibenclamide. Blood glucose levels were measured using blood glucose test strips and glucometer (Accu-chek Performa, Roche, Germany) at -30, 0, 30, 60 and $120 \mathrm{~min}$ after glucose loading to access the effect of MPE on blood glucose levels of the glucose loaded animals.

\section{Hypoglycemic activity study}

The rats were divided into the following six experimental groups with eight rats in each: group I: normal control rats treated orally with $0.5 \%$ Tween 80; group II: normal rats treated orally with glibenclamide $0.5 \mathrm{mg} / \mathrm{kg}$ bw; group III: normal rats administrated orally with MPE $500 \mathrm{mg} / \mathrm{kg}$ bw; group: IV diabetic control rats treated orally with $0.5 \%$ Tween 80 ; group V: diabetic rats treated orally with glibenclamide $0.5 \mathrm{mg} / \mathrm{kg}$ bw and group VI; diabetic rats administrated orally with MPE $500 \mathrm{mg} / \mathrm{kg}$ bw. MPE and glibenclamide were suspended in $0.5 \%$ Tween 80 and administered orally to the rats daily for 8 weeks using an orogastric tube. The volume of administration was $1 \mathrm{~mL}$ for each animal. The normal and STZ-induced diabetic rats were fasted overnight before the blood sample collection. The blood samples were taken from the tail vein of the rats. Fasting blood glucose level was measured weekly for 8 weeks using Glucometer (Accu-chek Performa, Roche, Germany).

\section{Hypolipidemic activity study}

After 8 weeks of treatment, the rats were fasted overnight. They were sacrificed by cervical dislocation technique, then blood samples were drawn from the rat's heart. The blood samples were centrifuged at $3500 \mathrm{rpm}$ for $20 \mathrm{~min}$ to separate blood serum. The biochemical data include total cholesterol (TC), triglycerides (TG), high-density lipoprotein (HDL) and low-density lipoprotein (LDL) which were measured by an automatic blood chemical analyzer (BT 2000 plus, Germany).

\section{Statistical analysis}

All data were expressed as mean \pm standard error of mean (SEM). Statistical analysis was carried out using $F$-test (One-Way ANOVA) followed by Scheffe's test. The criterion for statistical significance was at a $p$-value less than 0.05 .

\section{RESULTS}

Oral glucose tolerance test (OGTT)

Oral Glucose Tolerance Test, the blood samples were analyzed for glucose content at $-30,0,30,60$ and $120 \mathrm{~min}$, respectively. The blood glucose levels of MPE $(500 \mathrm{mg} / \mathrm{kg} \mathrm{bw})$ treated groups were showed that the doses of MPE could not decrease in normal and STZ-induced diabetic rats comparable to control and Glybenclamide treated at a -30 , 0,30 and $120 \mathrm{~min}$. Table 1.

\section{Hypoglycemic activity}

Table 2 showed the FBG in normal and STZ-induced diabetic rats. FBG in normal control, normal rats with glibenclamide and MPE were not effect. FBG with glibenclamide and MPE were significantly $(p<0.05)$ decreasing in diabetic rats. MPE at the dose of $500 \mathrm{mg} / \mathrm{kg}$ bw showed significantly $(\mathrm{p}<0.05)$ decreasing slightly better than control group at the 8 weeks of the experiment.

\section{Hypolipidemic activity}

Table 3 shows the effect of MPE on TC, TG, HDL and LDL in normal and diabetic rats. MPE at the doses of $500 \mathrm{mg} / \mathrm{kg}$ bw in normal rats, normal control, normal rats and normal glibenclamide were not effect. In diabetic rats, the levels of TC, TG and LDL at the doses of MPE and glibenclamide showed significantly decreased while MPE at the doses of $500 \mathrm{mg} / \mathrm{kg}$ bw significantly increased HDL when compared to the diabetic control group

\section{DISCUSSION}

A test widely used for glucose tolerance classification is the oral glucose tolerance test (OGTT). The OGTT is a widely used to evaluate apparent insulin release and insulin resistance in various clinical settings. ${ }^{19}$ For OGTT the blood samples were analyzed for glucose content at $-30,0,30$, 60 and $120 \mathrm{~min}$, respectively. In this oral glucose tolerance test study, the whole $M$. pudica plant, the single dosed study of MPE doses at $500 \mathrm{mg} /$ $\mathrm{kg}$ bw produced could not decrease in normal and STZ-induced diabetic rats. It's was compared with glibenclamide has been used for many years to treat diabetes and stimulates insulin secretion.

The present study, STZ $65 \mathrm{mg} / \mathrm{kg}$ bw was selected in order to partially destroy the $\beta$-cell of pancreas and consequently the rats became permanently diabetes. ${ }^{20}$ The result showed that MPE had a significant hypoglycemic effect by decreasing FPG after 8 weeks of treatment. MPE at the dose of $500 \mathrm{mg} / \mathrm{kg}$ bw showed more potent effect than control group in diabetic rats. ${ }^{7,17}$ MPE did not show a hypoglycemic effect in normal rats. We assume that hypoglycemia might not be induced by giving $M$. pudica to non-diabetes patients. Because MPE decreases FPG in diabetic rats, we assumed that it stimulates the insulin secretion. This effect is probably due to the regeneration of pancreatic $\beta$-cells which are destroyed by streptotozin. ${ }^{21}$ However, this proposed mechanism has to be clarified in a further study. The plant composition such as steroids, tannins, flavonoids and phenolic compounds have been reported. ${ }^{11}$ Constituents of MPE such as kaempferol and stigmasterol and flavonoids with their antioxidant activity may be responsible for this effect. ${ }^{22,23}$ Flavonoids such as kaempferol are known to improve insulin-stimulated glucose uptake in mature 3T3L1 adipocytes and to protected the body against free radicals, 
Yupparach and Konsue: Hypoglycemic and Hypolipidemic Activities of Ethanolic Extract from Mimosa pudica L.

Table 1: The end of oral glucose tolerance test (OGTT) result of MPE.

\begin{tabular}{ccccccc}
\hline \multirow{2}{*}{ Groups (mg/kg bw) } & \multicolumn{5}{c}{ Plasma glucose concentrations $(\mathrm{mg} / \mathrm{dL})$ at the time $(\mathrm{min})$ after glucose load } \\
\cline { 2 - 7 } & -30 & 0 & 30 & 60 & 90 & 120 \\
\hline NM Control & $90.50 \pm 4.21^{\mathrm{a}}$ & $107.67 \pm 7.94^{\mathrm{a}}$ & $168.00 \pm 6.11^{\mathrm{b}}$ & $131.00 \pm 8.61^{\mathrm{a}, \mathrm{b}}$ & $103.33 \pm 3.21^{\mathrm{a}, \mathrm{b}}$ & $96.00 \pm 3.54^{\mathrm{a}}$ \\
NM GB 0.5 & $92.83 \pm 4.00^{\mathrm{a}}$ & $112.83 \pm 2.88^{\mathrm{a}}$ & $123.50 \pm 9.83^{\mathrm{a}}$ & $78.33 \pm 7.36^{\mathrm{a}}$ & $68.83 \pm 5.38^{\mathrm{a}}$ & $63.33 \pm 5.39^{\mathrm{a}}$ \\
NM MPE 500 & $111.50 \pm 2.66^{\mathrm{a}}$ & $127.00 \pm 4.80^{\mathrm{a}}$ & $173.17 \pm 8.17^{\mathrm{b}}$ & $147.50 \pm 10.64^{\mathrm{b}}$ & $132.17 \pm 4.71^{\mathrm{b}}$ & $122.17 \pm 3.82^{\mathrm{a}}$ \\
DM Control & $367.00 \pm 16.19^{\mathrm{b}}$ & $422.00 \pm 18.35^{\mathrm{b}}$ & $530.50 \pm 15.29^{\mathrm{d}}$ & $470.83 \pm 15.29^{\mathrm{c}}$ & $404.83 \pm 13.16^{\mathrm{c}}$ & $375.17 \pm 10.53^{\mathrm{b}}$ \\
DM GB 0.5 & $356.33 \pm 53.52^{\mathrm{b}}$ & $380.83 \pm 48.25^{\mathrm{b}}$ & $473.50 \pm 28.15^{\mathrm{c}}$ & $451.83 \pm 36.51^{\mathrm{c}}$ & $383.00 \pm 34.52^{\mathrm{c}}$ & $322.17 \pm 52.91^{\mathrm{b}}$ \\
DM MPE 500 & $367.00 \pm 13.25^{\mathrm{b}}$ & $420.67 \pm 25.52^{\mathrm{b}}$ & $572.83 \pm 11.84^{\mathrm{d}}$ & $542.50 \pm 17.47^{\mathrm{d}}$ & $529.50 \pm 29.64^{\mathrm{d}}$ & $466.00 \pm 27.75^{\mathrm{c}}$ \\
\hline
\end{tabular}

The values represent the mean \pm SEM within the same row followed by the different superscript letters (a-d) are significantly different at the $\mathrm{p}<0.05$.

Table 2: The effect of MPE on 8 weeks fasting blood glucose levels in normal and STZ-induced diabetic rats.

\begin{tabular}{cccccccccc}
\hline \multirow{2}{*}{$\begin{array}{c}\text { Groups }(\mathbf{m g} / \\
\text { kg bw) }\end{array}$} & \multicolumn{7}{c}{ Plasma glucose concentrations (mg/dl) (weeks) } \\
\cline { 2 - 9 } & 0 & 1 & 2 & 3 & 4 & 5 & 6 & 7 \\
\hline NM Control & $95.17 \pm 1.76^{\mathrm{a}}$ & $92.17 \pm 4.09^{\mathrm{a}}$ & $96.33 \pm 1.52^{\mathrm{a}}$ & $87.33 \pm 3.02^{\mathrm{a}}$ & $95.17 \pm 3.90^{\mathrm{a}}$ & $96.00 \pm 2.48^{\mathrm{a}}$ & $87.17 \pm 1.30^{\mathrm{a}}$ & $96.17 \pm 3.28^{\mathrm{a}}$ & $88.17 \pm 1.96^{\mathrm{a}}$ \\
NM GB 0.5 & $89.67 \pm 2.35^{\mathrm{a}}$ & $92.67 \pm 4.16^{\mathrm{a}}$ & $95.33 \pm 1.26^{\mathrm{a}}$ & $98.17 \pm 5.26^{\mathrm{a}}$ & $92.83 \pm 2.63^{\mathrm{a}}$ & $95.00 \pm 2.11^{\mathrm{a}}$ & $90.00 \pm 0.37^{\mathrm{a}}$ & $91.17 \pm 1.47^{\mathrm{a}}$ & $89.50 \pm 2.54^{\mathrm{a}}$ \\
NM MPE 500 & $94.83 \pm 1.14^{\mathrm{a}}$ & $97.00 \pm 2.78^{\mathrm{a}}$ & $94.50 \pm 2.11^{\mathrm{a}}$ & $99.67 \pm 2.76^{\mathrm{a}}$ & $89.83 \pm 2.65^{\mathrm{a}}$ & $95.67 \pm 2.99^{\mathrm{a}}$ & $93.67 \pm 3.09^{\mathrm{a}}$ & $90.33 \pm 3.11^{\mathrm{a}}$ & $89.83 \pm 1.96^{\mathrm{a}}$ \\
DM Control & $357.17 \pm 15.85^{\mathrm{b}}$ & $523.00 \pm 35.41^{\mathrm{c}}$ & $456.67 \pm 15.73^{\mathrm{b}}$ & $525.17 \pm 15.63^{\mathrm{b}}$ & $520.33 \pm 19.95^{\mathrm{c}}$ & $566.33 \pm 26.48^{\mathrm{b}}$ & $423.17 \pm 14.74^{\mathrm{b}}$ & $541.00 \pm 22.56^{\mathrm{c}}$ & $506.50 \pm 11.91^{\mathrm{d}}$ \\
DM GB 0.5 & $371.67 \pm 31.26^{\mathrm{b}}$ & $421.00 \pm 20.13^{\mathrm{b}}$ & $492.17 \pm 25.07^{\mathrm{b}}$ & $504.67 \pm 18.79^{\mathrm{b}}$ & $434.00 \pm 40.37^{\mathrm{b}}$ & $537.67 \pm 9.73^{\mathrm{b}}$ & $496.83 \pm 33.58^{\mathrm{c}}$ & $473.67 \pm 35.93^{\mathrm{b}}$ & $444.83 \pm 15.81^{\mathrm{b}}$ \\
DM MPE 500 & $383.67 \pm 25.17^{\mathrm{b}}$ & $572.67 \pm 13.38^{\mathrm{c}}$ & $495.83 \pm 24.17^{\mathrm{b}}$ & $572.00 \pm 13.83^{\mathrm{c}}$ & $503.83 \pm 20.01^{\mathrm{c}}$ & $545.17 \pm 28.07^{\mathrm{b}}$ & $548.00 \pm 17.47^{\mathrm{d}}$ & $561.83 \pm 12.99^{\mathrm{c}}$ & $476.00 \pm 15.22^{\mathrm{c}}$ \\
\hline
\end{tabular}

The values represent the mean \pm SEM within the same row followed by the different superscript letters (a-d) are significantly different at the $\mathrm{p}<0.05$.

Table 3:Lipid Profiles of MPE in normal and STZ-induced diabetic rats.

\begin{tabular}{ccccc}
\hline & \multicolumn{4}{c}{ Lipid Profiles (mg/dl) } \\
\cline { 2 - 5 } Group (mg/kg bw) & $\begin{array}{c}\text { Total cholesterol } \\
(\mathrm{TC})\end{array}$ & $\begin{array}{c}\text { Triglycerides } \\
(\mathrm{TG})\end{array}$ & $\begin{array}{c}\text { Highdensity } \\
\text { lipoprotein (HDL) }\end{array}$ & $\begin{array}{c}\text { Lowdensity } \\
\text { lipoprotein (LDL) }\end{array}$ \\
\hline NM Control & $87.08 \pm 3.16^{\mathrm{a}}$ & $91.67 \pm 2.22^{\mathrm{a}}$ & $48.50 \pm 0.89^{\mathrm{b}, \mathrm{c}}$ & $20.25 \pm 3.26^{\mathrm{a}}$ \\
NM GB 0.5 & $101.17 \pm 1.28^{\mathrm{b}, \mathrm{c}}$ & $113.50 \pm 2.59^{\mathrm{b}, \mathrm{c}}$ & $51.17 \pm 1.97^{\mathrm{c}}$ & $27.30 \pm 1.33^{\mathrm{a}}$ \\
NM MPE 500 & $95.67 \pm 1.28^{\mathrm{a}, \mathrm{b}}$ & $102.17 \pm 1.51^{\mathrm{a}, \mathrm{b}}$ & $50.50 \pm 2.25^{\mathrm{b}, \mathrm{c}}$ & $24.73 \pm 1.51^{\mathrm{a}}$ \\
DM Control & $126.67 \pm 8.02^{\mathrm{d}}$ & $165.00 \pm 7.96^{\mathrm{e}}$ & $43.50 \pm 4.13^{\mathrm{a}, \mathrm{b}}$ & $50.17 \pm 5.37^{\mathrm{c}}$ \\
DM GB 0.5 & $106.00 \pm 2.57^{\mathrm{b}, \mathrm{c}}$ & $136.17 \pm 6.38^{\mathrm{d}}$ & $38.50 \pm 1.96^{\mathrm{a}}$ & $40.27 \pm 2.94^{\mathrm{b}}$ \\
DM MPE 500 & $111.67 \pm 2.09^{\mathrm{c}}$ & $121.67 \pm 2.79^{\mathrm{c}}$ & $46.33 \pm 1.31^{\mathrm{b}, \mathrm{c}}$ & $41.00 \pm 1.62^{\mathrm{b}}$ \\
\hline
\end{tabular}

The values represent the mean \pm SEM within the same row followed by the different superscript letters (a-d) are significantly different at the $\mathrm{p}<0.05$.

it is biologically plausible relation between flavonoids and low risk of diabetes. ${ }^{24,25}$

Diabetes is associated with alterations in the plasma lipid and lipoprotein profile, with an increased risk of coronary heart disease. ${ }^{26}$ Our data show that the level of HDL was increased, but levels of TC, TG, LDL in the diabetic rats were decreased. These results indicate that MPE possesses hypolipidemic effect in diabetic rats and thus may lead to a decrease in the risk of cardiovascular disease and related complications. The improvement of lipid profile might be directly or indirectly related to the reducing of FBG levels in diabetic rats ${ }^{27}$

\section{CONCLUSION}

The results from this study in particula whole plant of Mimosa pudica extract support the traditional use of the plant for diabetic treatment and health promoting agent for prevention of diabetes. The ethanolic extract at the dose of $500 \mathrm{mg} / \mathrm{kgbw}$ shows a beneficial hypoglycemic effect in diabetic rats. Further study, isolation and investigation of the chemical constituent of the extract from $M$. pudica responsible for the hypoglycemic effect should be undertaken in order to confirm and clarify the mechanism behind this activity.

\section{ACKNOWLEDGMENT}

The research was partially supported by the Development Research Division, Mahasarakham University. We thank Assoc. Prof. Dr. Chusri Talubmook for valuable discussion and a critical review of the manuscript.

\section{CONFLICT OF INTEREST}

The authors are declared no conflict of interest. 


\section{ABBREVIATION USED}

FBG: Fasting blood glucose levels; STZ: Streptozotocin; MPE: 80\% ethanolic extract; OGTT: Oral glucose tolerance test; TC: Total cholesterol; TG: Triglycerides; HDL: High-density lipoprotein; LDL: Low-density lipoprotein.

\section{REFERENCES}

1. Meo SA. Significance of spirometry in a diabetic patient with chronic cough. International Journal of Diabetes Mellitus. 2015;3(1):70-1.

2. American Diabetes 3. Association. Standards of medical care in diabetes-2008. Diabetes Care. 2008;31:12-54.

3. Chang CL, Lin Y, Bartolome AP, Chen YC, Chiu SC, Yang WC. Herbal therapies for type 2 diabetes mellitus: chemistry, biology, and potential application of selected plants and compounds. Evid Based Complement Alternat Med. 2013;378657:1-6.

4. Harrigan RA, Nathan MS, Beattie P. Oral agents for the treatment of type 2 diabetes mellitus: pharmacology, toxicity, and treatment. Ann Emer Med. 2001;38(1):68-78.

5. Rajkumar MH, Sringeswara AN, Rajanna MD. Ex-situ conservation of medicinal plants at university of agricultural sciences, Bangalore, Karnataka. Rec Res Sci Tech. 2011;3(4):21-7.

6. Kannan S, Aravinth S, Sam E, Kumar J, Saminathan K, Suthakaran R, et al. Wound healing activity of Mimosa pudica Linn formulation. Int J Chem Tech Res. 2009;11(4):1554-8.

7. Kokane DD, More RY, Kale KB, Nehete MN. Evaluation of wound healing activity of root of Mimosa pudica. J Ethnopharmacol. 2009;124(2):311-5.

8. Chandrashekar DK, Manthale DM. Invention of analgesic and anti-Inflammatory activity of ethanolic extract of Mimosa pudica Linn leaves. EJBPS. 2012;1(1): 36-8.

9. Manosroi J, Zaruwa Z, Moses, Manosroi W, Manosroi A. Hypoglycemic activity of Thai medicinal plants selected from the Thai/Lanna Medicinal Recipe Database MANOSROI II. J Ethnopharmacol. 2011;138(1):92-8.

10. Chowdhury SA, Islam J, Rahaman MMd, Rahman MMd, Rumzhum N, Sultana R, et al. Cytotoxicity, antimicrobial and antioxidant studies of the different plant parts of Mimosa pudica. SJPS. 2008;1(1-2):80-4

11. Suneetha B, Pavan KP, Prasad KVSRG, Vidyadhara S, Sambasiva RKRS. Hepatoprotective and antioxidant activities of methanolic extract of Mimosa pudica roots against carbon tetrachloride induced hepatotoxicity in albino rats. IRJP. $2011 ; 1(1): 46-53$

12. Rajendran R, Hemalatha S, Akasakalai K, MadhuKrishna CH, Sohil BV,
Sundaram MR. Hepatoprotective activity of Mimosa pudica leaves against Carbontetrachloride induced toxicity. J NAT PROD. 2009;2:116-22.

13. Sowmya A, Ananthi T. Hypolipidemic activity of Mimosa pudica Linn on butter induced hyperlipidemia in rats. AJPS. 2011;1(4):123-6.

14. Rajendran R, Krishnakumar E. Hypolipidemic activity of chloroform extract of Mimosa pudica leaves. AJMB. 2010;2(4):215-1.

15. Sutar NG, Sutar UN, Behera BC. Antidiabetic activity of Mimosa pudica Linn in albino rats. J Herb Med. 2009;3(1):123-6.

16. Konsue A, Picheansoonthon $\mathrm{C}$, Talubmook C. Fasting blood glucose levels and hematological values in normal and streptozotocin-induced diabetic rats of mimosa pudica L. Phcog J. 2017;9(3):315-12

17. Amalraj T, Ignacimuthu S. Hyperglycemic effect of leaves of Mimosa pudica Linn. Fitoterapia, 2002;73(4):351-2

18. Talubmook C. Effect of polysaccharide from Phellinus ignarius (L) Quel. On hematological values and blood cell characteristic in diabetic rats. JMST. 2008;22:42-5.

19. Stuvoll M, Jarvien HY, Mitrakou A, Haeften TV, Pimenta W, Renn W, et al. Use the oral glucose tolerance test to assess insulin release and insulin sensitivity. Diabetes Care. 2000;23(3):295-301.

20. Junod A, Lambert AE, Stauffacher W, Renold AE. Diabetogenic action of strep tozotocin: relationship of dose to metabolic response. JCI. 1969;48(11):2129-39. https://doi.org/10.1172/JCl106180; PMid:4241908 PMCid:PMC297467.

21. Eidi A, Eidi M, Esmaeili E. Antidiabetic effect of garlic (Allium sativum L.) in normal and streptozotocin-induced diabetic rats. Phytomedicine. 2006;13(9):624-9.

22. Nualkaew S, Padee P, Talubmook C. Hypoglycemic activity in diabetic rats

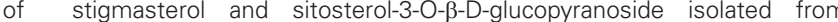
Pseuderanthemum palatiferum (Nees) Radlk. leaf extract. J Med Plants Res. 2015;9(20):629-35.

23. Ranjan RK, Kumar MS, Seethalakshmi I, Rao MRK, Phytochemical analysis of leaves and roots of Mimosa pudica collected from Kalingavaram, Tamil Nadu. JCHPS. 2013;5(5):53-5.

24. Seetharam YN, Chalageri G, Setty SR. Bheemachar. Hypoglycemic activity of Abutilon indicum leaf extracts in rats. Fitoterapia 2002;73(2):156-9.

25. Fang, XK, Gao J, Zhu DN. Kaempferol and quercetin isolated from Euonymus alatus improve glucose uptake of 3T3L1 cells without adipogenesis activity. Life Sciences 2008;82(11):615-22.

26. Maghrani M, Lemhadri A, Zeggwagh NA, El-Amraoui M, Haloui M, Jouad H et al. Effects of an aqueous extract of Triticum repens on lipid metabolism in normal and recent-onset diabetic rats. J Ethnopharmacol. 2004;90(2):331-7

27. Pierre W, Gildas AJ, Ulrich MC, Modeste WN, Benoît NT, Albert K. Hypoglycemic and hypolipidemic effects of Bersama engleriana leaves in nicotinamide/ streptozotocin-induced type 2 diabetic rats. BMC Complement Altern Med. 2012;12(1):264

\section{GRAPHICAL ABSTRACT}

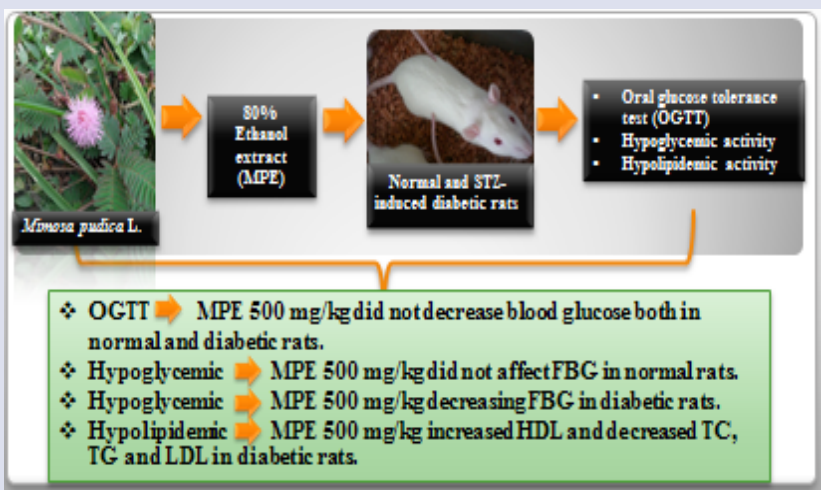

\section{SUMMARY}

- OGTT showed MPE $500 \mathrm{mg} / \mathrm{kg}$ did not decrease blood glucose both in normal and diabetic rats.

- Hypoglycemic showed MPE $500 \mathrm{mg} / \mathrm{kg}$ did not affect FBG in normal rats. MPE $500 \mathrm{mg} / \mathrm{kg}$ decreasing FBG in diabetic rats.

- Hypolipidemic showed MPE $500 \mathrm{mg} / \mathrm{kg}$ increased HDL and decreasedTC, TG and LDL in diabetic rats.

- The results from this study confirmed the traditional use of Mimosa pudica $\mathrm{L}$. for the treatment of diabetes mellitus.

- The ethanolic extract from Mimosa pudica has confirmed the traditional use of Mimosa pudica for the treatment of hypoglycemic and hypolipidemic in diabetes mellitus.

\section{ABOUT AUTHORS}

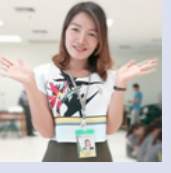

Ampa Konsue: Is a lecturer at the Faculty of Medicine, Mahasarakham University, Thailand, where she graduated in Bachelor of Sciences (Applied Thai Traditional Medicine) and Master of sciences (Pharmaceutical chemistry and natural products). Her doctoral research focused on theevaluation of hypoglycemic effect and mechanisms of actionand antioxidant activity of natural products.

Cite this article: Yupparach P, Konsue A. Hypoglycemic and Hypolipidemic Activities of Ethanolic Extract from Mimosa pudica L. in Normal and Streptozotocin-Induced Diabetic Rats. Pharmacog J. 2017;9(6):834-7. 